\title{
Genome-Wide Association Mapping and Gene Expression Analysis Reveal the Negative Role of OsMYB21 in Regulating Bacterial Blight Resistance in Rice
}

Wu Yang ${ }^{1,2 \dagger}$, Junliang Zhao ${ }^{1,2 \dagger}$, Shaohong Zhang ${ }^{1,2}$, Luo Chen ${ }^{1,2}$, Tifeng Yang ${ }^{1,2}$, Jingfang Dong ${ }^{1,2}$, Hua Fu ${ }^{1,2}$, Yamei Ma ${ }^{1,2}$, Lian Zhou ${ }^{1,2}$, Jian Wang ${ }^{1,2}$, Wei Liu ${ }^{1,2}$, Qing Liu ${ }^{1,2^{*}}$ and Bin Liu ${ }^{1,2^{*}}$ (i)

\begin{abstract}
Background: Bacterial blight (BB), caused by Xanthomonas oryzae pv. oryzae (Xoo), is one of the most devastating diseases in rice all over the world. Due to the diversity and rapid evolution of $X_{0 O}$, identification and use of the non-race specific quantitative resistance QTLs has been considered the preferred strategy for effective control of this disease. Although numerous QTLs for BB resistance have been identified, they haven't been effectively used for improvement of BB resistance in rice due to their small effects and lack of knowledge on the function of genes underlying the QTLS.

Results: In the present study, a genome-wide association study of BB resistance was performed in a rice core collection from South China. A total of 17 QTLs were identified to be associated with BB resistance. Among them, 13 QTLs were newly identified in the present study and the other 4 QTLs were co-localized with the previously reported QTLs or Xa genes that confer qualitative resistance to Xoo strains. Particularly, the qBBR11-4 on chromosome 11 explained the largest phenotypic variation in this study and was co-localized with the previously identified QTLs for BB and bacterial leaf streak (BLS) resistance against diverse strains in three studies, suggesting its broad-spectrum resistance and potential value in rice breeding. Through combined analysis of differential expression and annotations of the predicted genes within qBBR11-4 between two sets of rice accessions selected based on haplotypes and disease phenotypes, we identified the transcription factor OsMYB21 as the candidate gene for qBBR11-4. The OSMYB21 overexpressing plants exhibited decreased resistance to bacterial blight, accompanied with down-regulation of several defense-related genes compared with the wild-type plants.

Conclusion: The results suggest that OSMYB21 negatively regulates bacterial blight resistance in rice, and this gene can be a promising target in rice breeding by using the gene editing method. In addition, the potential candidate genes for the 13 novel QTLs for BB resistance were also analyzed in this study, providing a new source for cloning of genes associated with $\mathrm{BB}$ resistance and molecular breeding in rice.
\end{abstract}

Keywords: GWAS, Bacterial blight, OsMYB21, Rice

\footnotetext{
*Correspondence: liuging198504@126.com; Ibgz1009@163.com

${ }^{+}$Wu Yang and Junliang Zhao contributed equally to this work.

${ }^{1}$ Rice Research Institute, Guangdong Academy of Agricultural Sciences,

Guangzhou 510640, China

Full list of author information is available at the end of the article
}

\section{Springer Open}

(c) The Author(s). 2021 Open Access This article is licensed under a Creative Commons Attribution 4.0 International License, which permits use, sharing, adaptation, distribution and reproduction in any medium or format, as long as you give appropriate credit to the original author(s) and the source, provide a link to the Creative Commons licence, and indicate if changes were made. The images or other third party material in this article are included in the article's Creative Commons licence, unless indicated otherwise in a credit line to the material. If material is not included in the article's Creative Commons licence and your intended use is not permitted by statutory regulation or exceeds the permitted use, you will need to obtain permission directly from the copyright holder. To view a copy of this licence, visit http://creativecommons.org/licenses/by/4.0/. 


\section{Background}

Bacterial blight (BB), caused by Xanthomonas oryzae $p v$. oryzae (Xoo), is one of the most devastating rice diseases all over the world (Savary et al. 2019). Nowadays, developing and deploying resistance rice cultivars is considered the most economic and environmentally friendly way to control this disease (Zhang et al. 2017). Rice resistance against $\mathrm{BB}$ can be generally divided into two main categories, the qualitative resistance controlled by major resistance $(R)$ genes, and the quantitative resistance conferred by multiple minor genes or quantitative trait loci (QTLs) (Ramalingam et al. 2003; Deng et al. 2012; Bossa-Castro et al. 2018). So far, over $40 R$ genes that confer qualitative resistance to BB has been identified (Jiang et al. 2020) and 11 of them (Xa1,Xa3/Xa26, Xa4, xa5, Xa10, xa13, Xa21, Xa23, xa25, Xa27, xa41) have been cloned successfully by using map-based cloning strategy or knowledge-based molecular screening (Yoshimura et al. 1998; Han et al. 2014; Hutin et al. 2015; Wang et al. 2015; Ji et al. 2018). The $R$ genes with comparatively broader spectra of resistance, such as Xa3, Xa4, Xa7, $x a 13, X a 21$ and $X a 23$, have been widely used in rice breeding programs, and many resistant rice cultivars have been released (Huang et al. 1997; Han et al. 2014; Wang et al. 2015; Zhang et al. 2015; Hu et al. 2017; Jiang et al. 2020). Although the disease resistance conferred by a single $R$ gene is usually effective against certain races of the Xoo pathogen, the resistance is easily breakdown due to a greater selection pressure on pathogen evolution. Conversely, the quantitative resistance mediated by QTLs is presumably non-race specific and is considered to be more durable (Liu et al. 2016). Thus, it has attracted more attention in the past decades and more than 70 QTLs for BB resistance have been identified ( $\mathrm{Li}$ et al. 2006; Han et al. 2014; Djedatin et al. 2016; Dilla-Ermita et al. 2017; Zhang et al. 2017; Bossa-Castro et al. 2018). Despite quantitative resistance has been considered as a preferred strategy to achieve durable resistance and numerous QTLs for BB resistance have been identified, marker-assisted selection has not been effectively used for improvement of $\mathrm{BB}$ resistance in rice. This issue is attributed to the polygenic nature of the trait and each QTL has small effect. It is difficult to accumulate multiple QTLs with small effects in breeding. In addition, most of the QTLs for BB resistance were identified and mapped using bi-parental population QTL analysis in the past decades. Because of limited molecular markers used and less recombinants in a primary mapping population, most of the QTLs for BB resistance are mapped to a region of $10 \sim 30 \mathrm{cM}$. Since a prerequisite for successful marker-assisted selection (MAS) is the availability of the markers that closely linked with the target gene, the inaccuracy of QTL mapping hinders the application of MAS. Therefore, discovery of the large-effect QTLs and use of a more powerful approach for genetic dissection of complex traits are crucial to address this issue.

Encouragingly, the rapid development of high through-put sequencing technology, SNP array technology and their applications for genotyping lead to the development of genome-wide association study (GWAS). Compared with conventional bi-parental population QTL analysis, GWAS has two main advantages: (1) it can use nature population instead of bi-parental population. The rice varieties used in GWAS contain much more genetic diversity than the bi-parental lines used in segregation populations. Because of using diverse germplasm for QTL mapping in GWAS, it favors the identification of large-effect and novel QTLs; (2) most GWAS can result in a relatively high mapping resolution due to the existence of numerous historical recombination events (Takeda and Matsuoka 2008) and using plenty of SNPs for association mapping. Therefore, GWAS provides a powerful tool for large-scale and precise identification of QTLs for the complex traits like BB resistance in germplasm (Zhao et al. 2011; Han and Huang 2013; Zhang et al. 2017; Zhai et al. 2018).

To search for large-effect and novel BB resistant QTLs and their causal genes, GWAS of BB resistance was conducted using a diverse core panel consisting of 255 landraces and 58 modern varieties from South China which have been sequenced in the present study. We identified 17 QTLs for BB resistance, including 13 novel QTLs and 4 known QTLs/genes identified in the previous studies, implying the reliability of the GWAS results and diversity of the rice germplasm used in this study. Among the 17 QTLs for BB resistance, $q B B R 11-4$ explained the largest diseased phenotypic variation. Through gene differential expression analysis, annotations of the predicted genes within qBBR11-4 and transgenic analysis, the MYB transcription factor 21 (OsMYB21), Os11g0684000, was validated as the functional target genes underlying the QTL qBBR11-4. The OsMYB21 overexpressing plants showed significantly increased susceptibility to bacterial blight. Moreover, the expression levels of several pathogenesis-related $(P R)$ genes were remarkably down-regulated in the transgenic plants compared to the wild-type plants. The results from this study provides good sources for discovery of new genes related to bacterial blight resistance, and OsMYB21 can be a promising target in rice breeding by using the gene editing method.

\section{Results}

The Phylogenetic Analysis of the Core Collection and their Reactions to Bacterial Blight

The 313 rice accessions used in this study are the core collection of the rice germplasms collected by Guangdong Academy of Agricultural Science, China. This core 
collection was selected from grouping of the original germplasm based on their 26 traits and genotypes determined by 384 SNPs, and represents $90 \%$ of the diversity of the original collection (unpublished data). The core collection panel consists of 255 landraces and 58 modern cultivars from South China (Table S1). All the accessions were genotyped using next-generation sequencing technology and 643,841 SNPs were selected for phylogenetic and GWAS analysis in the present study. The population structure of the panel was shown by phylogenetic tree (Fig. 1A). According to the phylogenetic tree, 313 rice accessions can be roughly clustered into 3 major groups (Fig. 1A, indicated as I, II and III).

The 313 rice accessions were inoculated with isolate CI-4 from the Chinese Xoo race 4, the dominant race in South China, at the booting stage. Most of the 313 rice accessions showed highly susceptible to Xoo, with percent lesion length (lesion length/leaf length) more than 50\% (Fig. 1B and Table S1). The modern cultivar "Xinbaoai" (No. L56) showed the strongest resistance, with percent lesion length of $0.46 \%$ (Table S1). The average percent lesion length of landraces was significantly longer than that of modern cultivars (Fig. 1C).

\section{Mapping of QTLs for Bacterial Blight Resistance by GWAS}

Based on the criteria of having less than $15 \%$ missing data and minor allele frequency (MAF) larger than $5 \%$ in the population, 643,841 SNPs were selected for GWAS analysis. Totally, 17 QTLs with 716 SNPs were significantly associated with bacterial blight resistance in the 313 rice accessions (Table 1, Fig. 2A and Table S2). These QTLs (designate as $q B B R$ hereafter) were distributed on chromosomes $1,4,6,7,8,9,10$ and 11, respectively (Table 1 and Fig. 2A). Compared with the previous reports, four QTLs (qBBR10-2, qBBR11-4, qBBR11-5, $q B B R 11-6)$ identified in this study were co-localized with the previously reported QTLs or $X a$ genes as shown in Table 1, Fig. 2C and D. The other 13 QTLs were newly identified in the present study.

\section{Candidate Gene Analysis of $q B B R 11-4$}

Among the 17 QTLs identified in the present study, qBBR11-4 explained the largest phenotypic variation in the population (Table 1). Moreover, qBBR11-4 was colocalized with the previously reported QTLs (QBbr11, $q A B B-11$ and $q X O-11-2)$, which were detected to be resistant to the strains from different pathotypes in Africa and Asia (Zhang et al. 2015; Djedatin et al. 2016; Bossa-Castro et al. 2018), suggesting its broad spectrum resistance to $\mathrm{BB}$ and potential value in rice breeding. Therefore, we further conducted candidate gene analysis of qBBR11-4. Because the rice linkage disequilibrium block is about 100-200 kb (Wang et al. 2020), a 400-kb region (27.37$27.77 \mathrm{Mb}, 200 \mathrm{~kb}$ up and down stream of the most

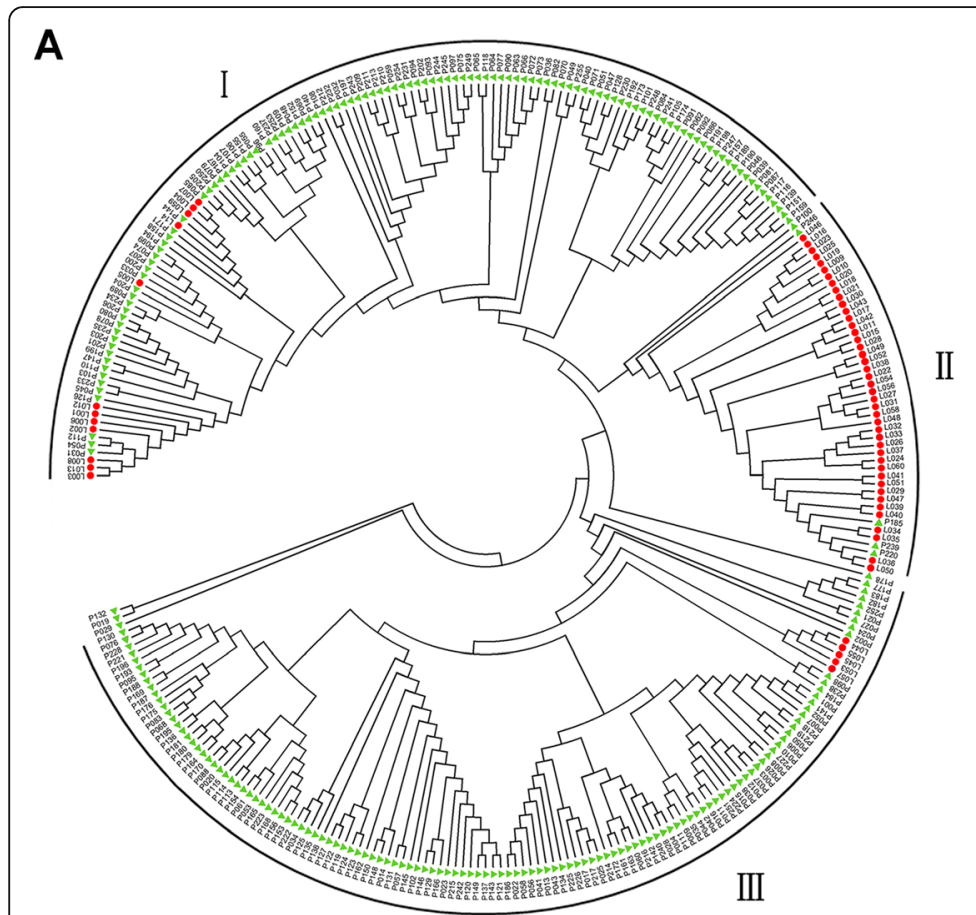

B

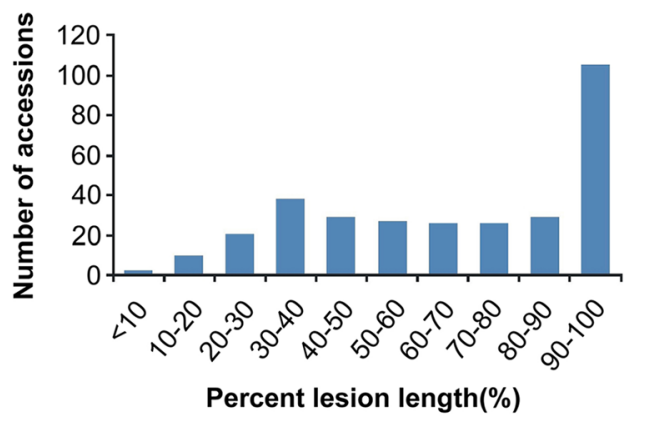

C

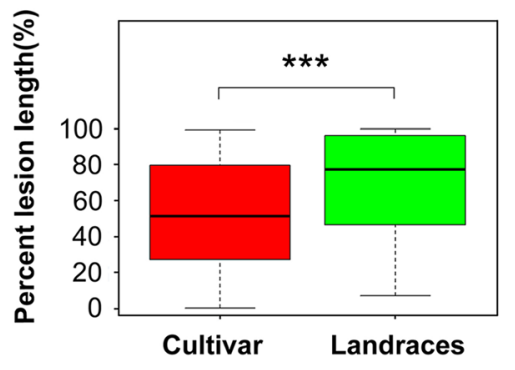

Fig. 1 The phylogenetic tree and phenotypic distribution of 313 rice accessions used in this study. A The phylogenetic tree of 313 rice accessions. The round (red) and trigonal (green) shape represent modern cultivar and landraces, respectively. B Phenotypic distribution of 313 rice accessions. C Comparison of the average percent lesion length between modern cultivars and landraces. Asterisk indicates significant difference (Student's $t$-test, ${ }^{* * *} P<0.001$ ) 
Table 1 QTLs associated with rice bacterial blight resistance identified in this study

\begin{tabular}{|c|c|c|c|c|c|c|c|}
\hline QTLs & Chromosome & $\begin{array}{l}\text { Linked SNP } \\
\text { position }^{\mathrm{a}}\end{array}$ & $\begin{array}{l}\text { Major/ } \\
\text { Minor allele }\end{array}$ & $P$-value & $\begin{array}{l}\text { Phenotypic } \\
\text { variation explained (\%) }\end{array}$ & $\begin{array}{l}\text { Overlapping } \\
\text { locus/gene }\end{array}$ & Reference \\
\hline qBBR1 & 1 & $1,936,376$ & $\mathrm{~A} / \mathrm{G}$ & $2.84838 \mathrm{E}-06$ & 4.03 & & \\
\hline qBBR4-1 & 4 & $1,845,370$ & $A / G$ & $3.51716 \mathrm{E}-07$ & 4.81 & & \\
\hline$q B B R 4-2$ & 4 & $5,493,782$ & $\mathrm{G} / \mathrm{A}$ & $2.26586 \mathrm{E}-05$ & 3.28 & & \\
\hline qBBR6-1 & 6 & $18,070,061$ & $\mathrm{~A} / \mathrm{C}$ & $3.53715 \mathrm{E}-05$ & 3.12 & & \\
\hline$q B B R 6-2$ & 6 & $19,329,090$ & $\mathrm{~T} / \mathrm{C}$ & 4.16516E-05 & 3.06 & & \\
\hline$q B B R 7-1$ & 7 & $23,433,761$ & $\mathrm{G} / \mathrm{A}$ & $3.2846 \mathrm{E}-05$ & 3.14 & & \\
\hline$q B B R 7-2$ & 7 & $29,527,042$ & $A / G$ & $2.74836 \mathrm{E}-08$ & 5.78 & & \\
\hline qBBR8 & 8 & $5,432,150$ & $C / T$ & $6.56414 \mathrm{E}-05$ & 2.90 & & \\
\hline$q B B R 9$ & 9 & $8,986,663$ & $\mathrm{G} / \mathrm{A}$ & $3.03815 \mathrm{E}-05$ & 3.17 & & \\
\hline $\begin{array}{l}\text { qBBR10- } \\
1\end{array}$ & 10 & $19,158,528$ & $A / G$ & $2.32191 \mathrm{E}-07$ & 4.96 & & \\
\hline $\begin{array}{l}q B B R 10- \\
2\end{array}$ & 10 & $20,261,868$ & $\mathrm{~T} / \mathrm{C}$ & 5.27067E-05 & 2.97 & $\begin{array}{l}q \times O-10-1, q A B B- \\
10\end{array}$ & $\begin{array}{l}\text { Gustave et al. 2016; } \\
\text { Bossa-Castro et al. } 2018\end{array}$ \\
\hline $\begin{array}{l}\text { qBBR11- } \\
1\end{array}$ & 11 & $3,064,808$ & $\mathrm{~A} / \mathrm{T}$ & 4.41216E-05 & 3.04 & & \\
\hline $\begin{array}{l}\text { qBBR11- } \\
2\end{array}$ & 11 & $4,364,433$ & $A / G$ & $2.46251 \mathrm{E}-05$ & 3.25 & & \\
\hline $\begin{array}{l}\text { qBBR11- } \\
3\end{array}$ & 11 & $26,432,751$ & $C / A$ & 1.37316E-06 & 4.30 & & \\
\hline $\begin{array}{l}\text { qBBR11- } \\
4\end{array}$ & 11 & $27,573,275$ & $C / A$ & 4.72312E-09 & 6.46 & $\begin{array}{l}\text { QBbr11, aXO- } \\
11-2, a A B B-11\end{array}$ & $\begin{array}{l}\text { Zhang et al. 2015; Gustave et al. } \\
\text { 2016; Bossa-Castro et al. } 2018\end{array}$ \\
\hline $\begin{array}{l}\text { qBBR11- } \\
5\end{array}$ & 11 & $28,484,065$ & $\mathrm{G} / \mathrm{A}$ & 7.47E-06 & 3.68 & $\begin{array}{l}X a 3 / X a 26, X a 4, \\
X a 40, x a 43(t) \\
x a 44(t)\end{array}$ & $\begin{array}{l}\text { Sun et al. 2003; Cao et al. 2007; Kim } \\
\text { et al. 2015; Kim 2018; Kim and } \\
\text { Reinke } 2019\end{array}$ \\
\hline $\begin{array}{l}q B B R 11- \\
6\end{array}$ & 11 & $28,759,500$ & $C / T$ & 4.64E-06 & 3.85 & L11 & Zhang et al. 2017 \\
\hline
\end{tabular}

significant SNP within $q B B R 11-4$ ) was used for candidate gene analysis. According to the Rice Annotation Project (RAP) (Kawahara et al. 2013), the region contains 28 functionally annotated genes excluding the retrotransposons. Referring to the gene function annotation, gene ontology classification and RNA-seq FPKM expression data shown in RAP, we lastly selected 11 potential candidate genes for transcription analysis (Table S3). Based on the diseased phenotypes and haplotype analysis of $q B B R 11-4,3$ rice accessions with Xoo-resistance haplotype and Xoo-resistance phenotype, and 3 rice accessions with Xoo-susceptible haplotype and Xoo-susceptible phenotype were selected for gene differential expression analysis. The expression levels of 11 potential candidate genes in the 6 rice accession were evaluated both befor and after pathogen inoculation. The real-time PCR analyses were conducted at $0 \mathrm{~h}, 12 \mathrm{~h}, 24 \mathrm{~h}$ and $48 \mathrm{~h}$, respectively. The results showed that only two genes (LOC_Os11g45740, i.e. OsMYB21 and LOC_Os11g45750, i.e. OsWRKY125) displayed significantly induced expression pattern after pathogen infection in both Xoo-resistance and Xoo-susceptible rice accessions (Fig. 3). Five genes showed inconsistent differential expression between the resistant and susceptible rice accessions (Figure S1), and the expression of the left four genes (LOC_Os11g45060, LOC_ Os11g45924, LOC_Os11g45920 and LOC_Os11g45330) were not detected in these accessions (Table S4). The transcription of OsMYB21 was remarkably activated at all time points after pathogen inoculation, whereas the transcription of OsWRKY125 was only increased at $12 \mathrm{~h}$ after Xoo infection (Fig. 3). Moreover, we also discovered that OsMYB21 showed significantly lower transcript levels in Xoo-resistant accessions than in Xoo-susceptible accessions while OsWRKY125 displayed no obvious expression difference between the two sets of varieties with contrast disease resistance (Fig. 3). We found that a 2-bp insertion in the TC-rich repeats at $154 \mathrm{bp}$ before initiator codon in the promoter regions of OsMYB21 in the Xoo-susceptible accessions compared with the Xoo-resistant accessions (Figure S2). These results together suggest that OsMYB21 could be the candidate gene of $q B B R 11-4$.

\section{Functional Validation of OsMYB21}

To confirm the function of OsMYB21 in bacterial blight resistance, we firstly compared the protein sequences between Nipponbare, Xoo-resistance and Xoo-susceptible 


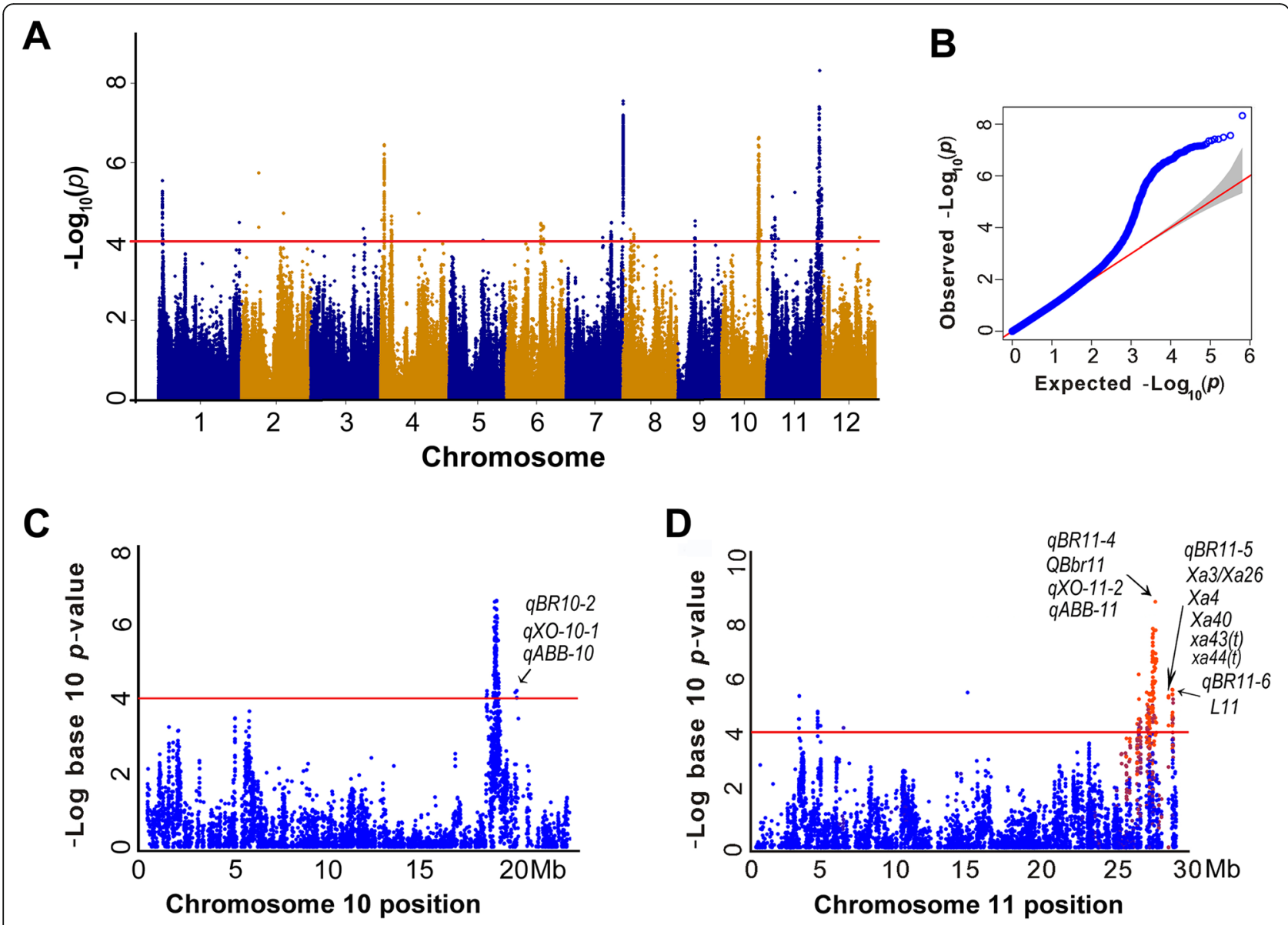

Fig. 2 GWAS analysis for bacterial blight resistance in 313 rice accessions. A Manhattan plots of bacterial blight resistance in 12 chromosomes. B QQ-plot for GWAS of bacterial blight resistance. C Co-localization of qXO-10-1 and qABB-10 with qBBR10-2. D Co-localization of QBbr-11, qXO-11-2 and $q A B B-11$ with $q B B R 11-4 ; X a 3 / X a 26, X a 4, X a 40, X a 43(t)$ and $X a 44(t)$ with $q B B R 11-5 ; L 11$ with $q B B R 11-6$. The red line indicates the significance threshold set at $P=1.0 \times 10^{-4}$

accessions used in transcription analysis, and found no consistent difference (Figure S3). Transgenic plants constitutively overexpressing OsMYB21 (MYB21OE) were produced in Nipponbare which are susceptible to Xoo CI-4. Twenty-one transgenic lines overexpressing the genotype "P91" [MYB21(P91)-OE] and 24 transgenic lines overexpressing the genotype "Nipponbare" [MYB21(Nip)-OE] were obtained, respectively, and they all showed no significant difference in the non-target traits when compared to the wild-type plants (data not shown). Two independent homozygous lines of each genotype were selected for further evaluation. Gene transcriptional analysis revealed that the expression of OsMYB21 was significantly increased in these transgenic plants (Fig. 4). The MYB21OE plants of two genotypes all showed remarkably increased susceptibility to bacterial blight, with lesion lengths ranging from 10.12 to $13.73 \mathrm{~cm}$, compared to $8.0 \mathrm{~cm}$ for the wild-type Nipponbare plants $(p<0.01)$ (Fig. 4).
The Relationship between OsMYB21 and PathogenesisRelated Genes in Regulating Disease Resistance in Rice Previous study has reported that three MYB transcription factors mediate disease resistance through regulation of $P R$ genes in wheat (Zhang et al. 2012; Liu et al. 2013; Shan et al. 2016). To determine if OsMYB21 mediated disease susceptibility was through regulating the expression of $P R$ genes, the transcription levels of six $P R$ genes were analyzed in the wildtype Nipponbare and four MYB21OE plants both before and after Xoo inoculation. The results showed that pathogen infection strongly induced the expression of PR1a, PR2 and PR5-1 but reduced the expression of PR3, PR5 and PR10 in both the wild-type and MYB21OE plants before and after Xoo inoculation. The transcription levels of $P R 1 a, P R 2$ and $P R 10$ were significantly down-regulated in MYB21OE plants compared with the wild-type plants before and after pathogen inoculation (Fig. 5). 


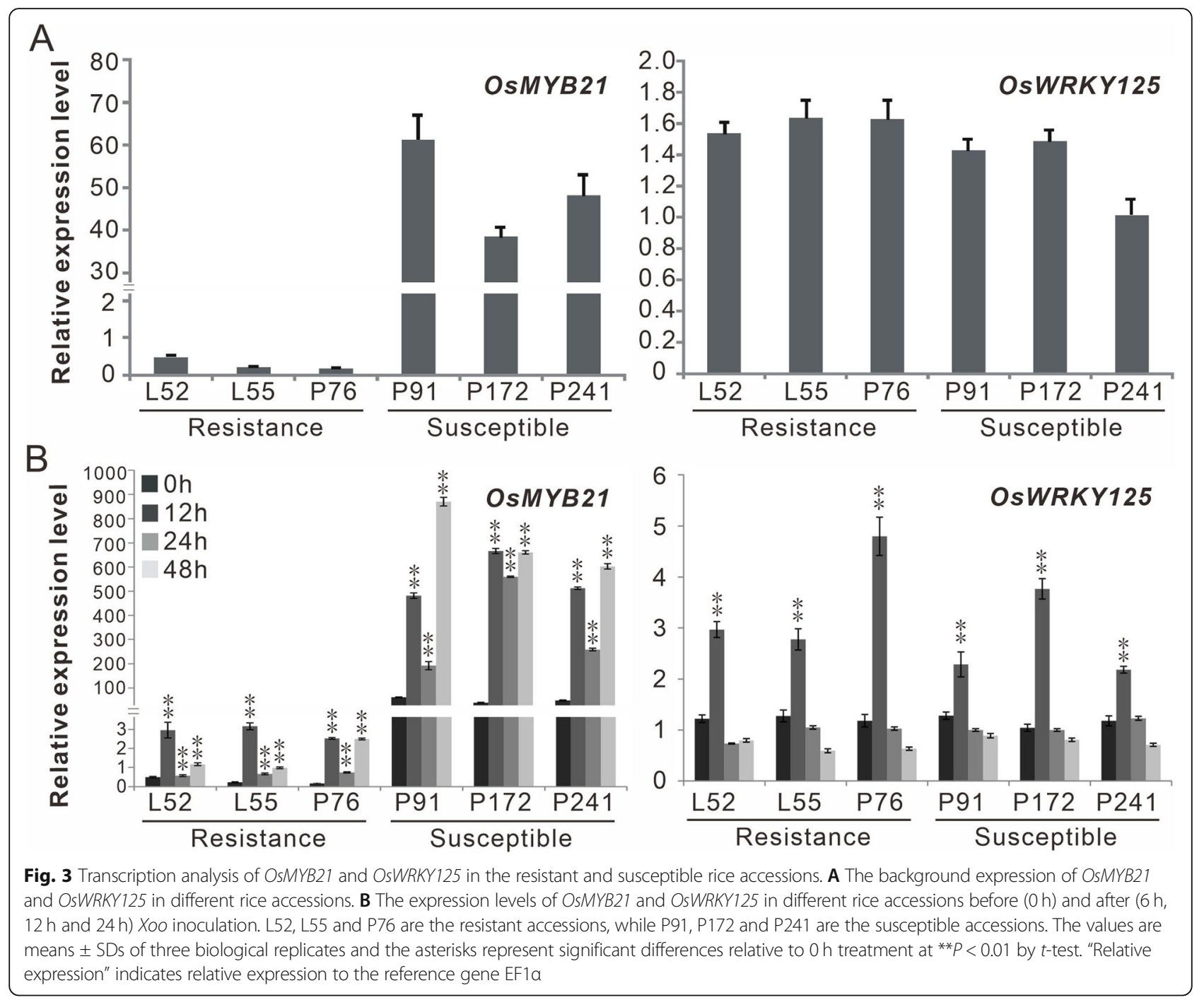

\section{Discussion}

\section{The qBBR11-4 Has a Great Potential Value in Rice} Breeding

In the present study, the evaluation of $\mathrm{BB}$ resistance of the core rice panel from South China showed that among the 313 accessions, only 5 accessions were resistant (disease scale lower than 3 or lesion area less than $12 \%)$ to $C I-4$, a BB isolate from the dominant race 4 in South China (Table S1), suggesting the difficulty in rice breeding for $\mathrm{BB}$ resistance. In the past decades, rice breeding for $\mathrm{BB}$ resistance largely relies on $R$ gene resistance. This type of disease resistance is easily overcome due to the diversity and variability of the pathogen. The short-lived span of BB resistance for most of rice cultivars has been a major issue in rice production. Although deployment of the non-race specific quantitative resistance has been proposed as a good strategy to achieve durable resistance, this strategy has not been successfully carried out in rice breeding due to the polygenic nature and lack of knowledge on the functional genes underlying the QTLs.

To identify the genes associated with quantitative $\mathrm{BB}$ resistance, GWAS of BB resistance was performed using a diverse rice core collection from South China in this study. In total, 17 QTLs associated with BB resistance were identified. Among the 17 QTLs, qBBR11-4 explained the largest variations of $B B$ resistance in the population (Table 1). It is noteworthy that qBBR11-4 overlaps with the previously identified QTLs for broadspectrum $B B$ resistance, $q X O-11-2, q A B B-11$ and QBbr11 (Zhang et al. 2015; Djedatin et al. 2016; BossaCastro et al. 2018). The $q X O-11-2$ was detected to be resistant to five African Xoo strains from different pathotypes (Bossa-Castro et al. 2018) while $q A B B-11$ was detected to be resistant to four African strains and the Philippine isolate PXO61 (Djedatin et al. 2016), and QBbr11 was identified to be resistant to three isolates representing Pathotype II, Pathotype IV and Pathotype 


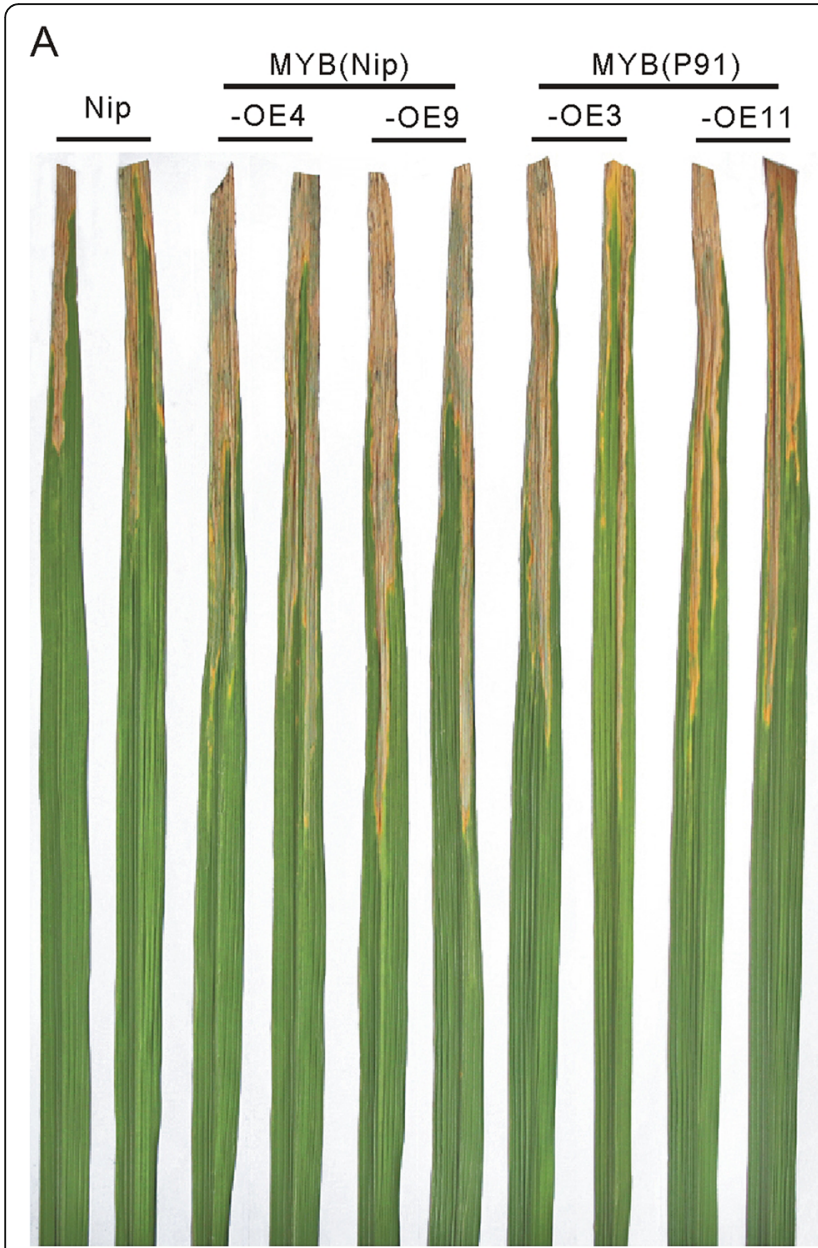

B

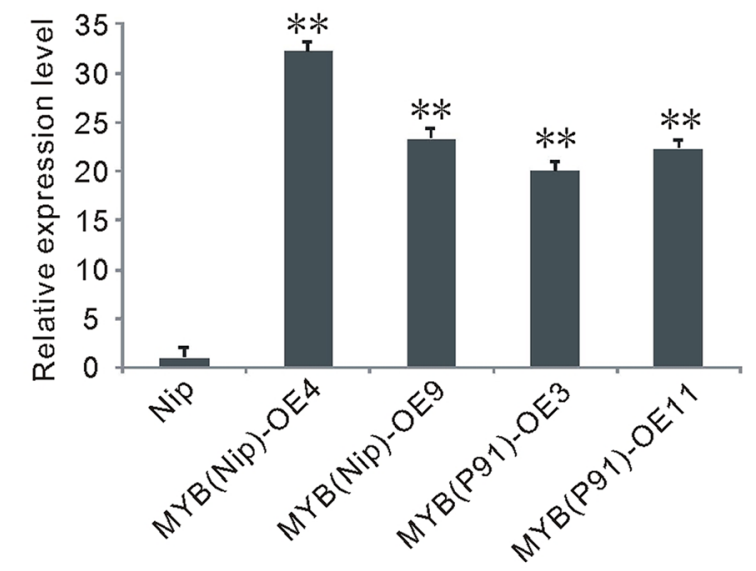

C

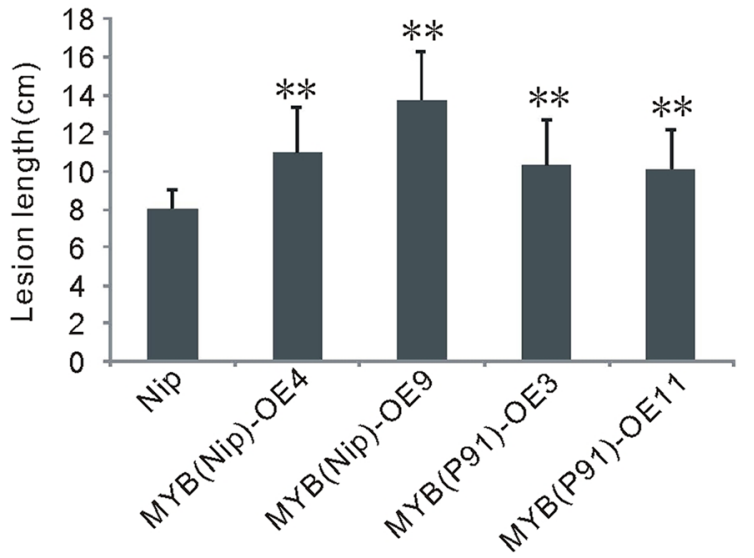

Fig. 4 Functional validation of OSMYB21. A The phenotypes of wild-type Nipponbare and OSMYB21 overexpressing plants after XoO inoculation. MYB21(P91)-OE indicates the transgenic lines overexpressing the genotype "P91" of OsMYB21, and MYB21(Nip)-OE indicates the transgenic lines overexpressing the genotype "Nipponbare" of OSMYB21. B Relative expression levels of OsMYB21 in the wild-type Nipponbare and transgenic plants. The values are means \pm SDs of three biological replicates. C Relative lesion length in the wild-type Nipponbare and transgenic plants after Xoo inoculation. The values are means \pm SDs of at least twenty leaves. Asterisks represent significant differences relative to $0 \mathrm{~h}$ treatment at ${ }^{* *} P<$ 0.01 by $t$-test

$\mathrm{V}$, respectively (Zhang et al. 2015). These results together suggest that the qBBR11-4 identified in the present study could be a broad-spectrum $B B$ resistant QTL. Its large phenotypic effect and broad-spectrum BB resistance make $q B B R 11-4$ have a great potential value in rice breeding.

\section{OsMYB21 Can Be a Promising Target for Improvement of BB Resistance in Rice}

To identify the gene underlying $q B B R 11-4$, a 400-kb region was chosen for gene annotation referring to the previous reports (Kawahara et al. 2013; Zhao et al. 2018). After filtering the retrotransposons, nonexpressed genes and differential expression analysis of the genes within $q B B R 11-4$ using two sets of rice accessions with contrast BB resistance before and after Xoo inoculation, OsMYB21 was identified as the only candidate gene for qBBR11-4 (Fig. 3, Figure S1 and Table S4). Based on DNA re-sequencing, a 2-bp variation in the TC-rich repeats of the promoter was found (Figure S2). TC-rich repeats have been detected in the promoter region of many plant disease-resistance genes (Germain et al. 2012). Therefore, the 2-bp difference in the promoter may result in different OsMYB21 expression profiles in the resistant cultivars and susceptible cultivars. The previous study reported that OsMYB21 carried the binding target site of TAL effector of XOO2127_MAFF (Grau et al. 2013), further suggesting the possible role of OsMYB21 in bacterial blight resistance. The transgenic plants overexpressing OsMYB21 exhibited decreased bacterial blight resistance as manifested by the longer lesions compared with wild-type Nipponbare plants (Fig. 4). Thus, our results suggest that OsMYB21 is the causal gene of $q B B R 11-4$ and negatively 

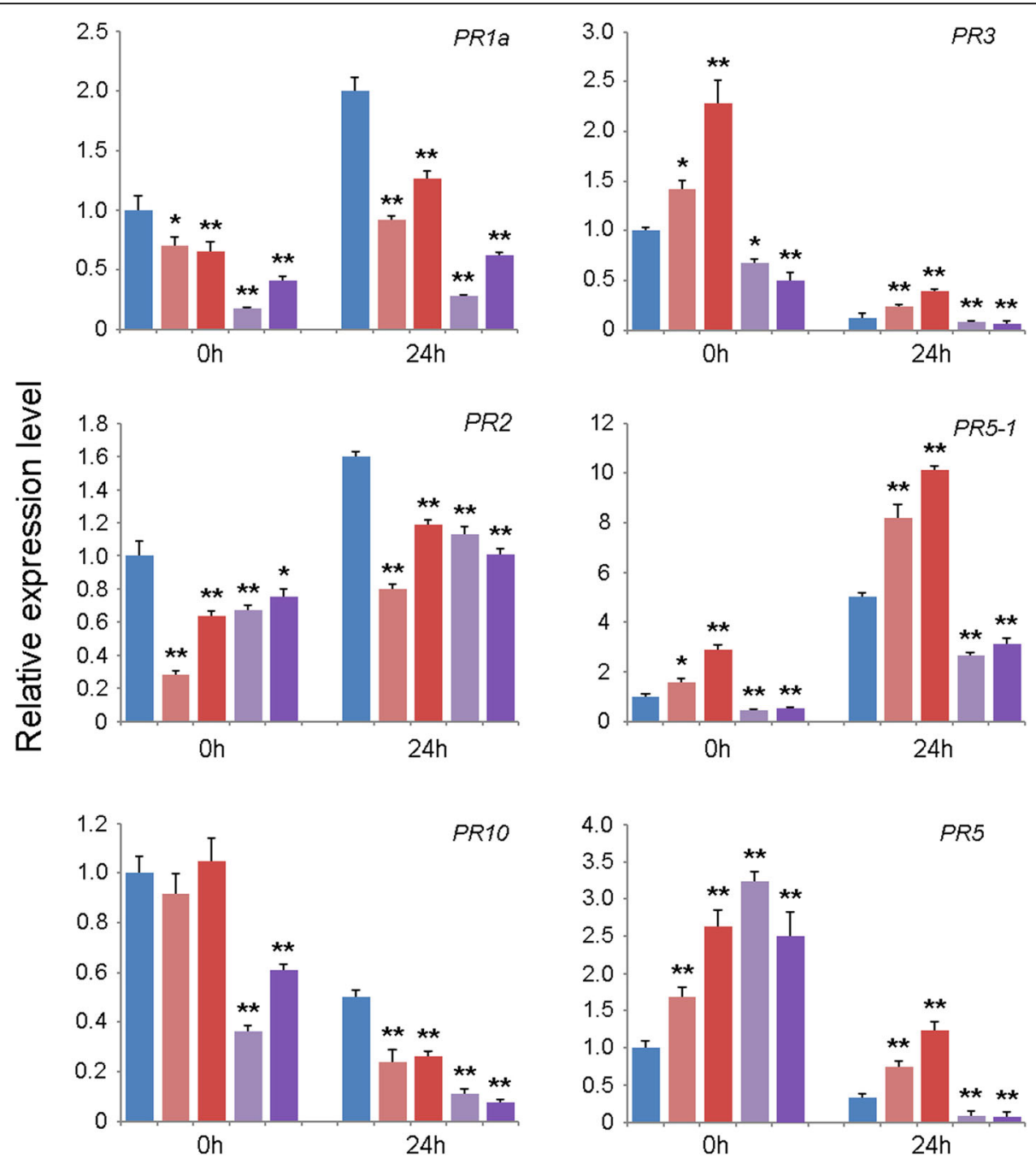

¿Nip $\square$ MYB(Nip)-OE4 $\square$ MYB(Nip)-OE9

MYB(P91)-OE3 पMYB(P91)-OE11

Fig. 5 The expression levels of six PR genes in the wild-type Nipponbare and transgenic plants before $(0 \mathrm{~h})$ and after $(24 \mathrm{~h}) X_{0 O}$ inoculation. The values are means \pm SDs of three biological replicates and the asterisks represent significant differences relative to wild-type plants at ${ }^{* *} P<0.01$ and ${ }^{*} P<0.05$ by t-test. The transcript level of Nipponbare was set to " 1 " at $0 \mathrm{~h}$ treatment. "Relative expression" indicates relative expression to the reference gene EF1a

regulates $\mathrm{BB}$ resistance in rice. The negative role of OsMYB21 implies that this gene can be a promising target for improvement of $\mathrm{BB}$ resistance in rice by means of gene editing method. It is noteworthy that the induction of OsMYB21 by the BB isolate CI-4 and the bacterial blight susceptibility mediated by OsMYB21 might be related to the TAL effector of CI-4. It will be particularly interesting to determine if any TAL effector targets overlap the 2-bp deletion found in Xoo-resistant accessions.

As one of the largest families of transcription factors, many MYB genes have been demonstrated as important regulators in plant responses to both biotic and abiotic stresses (Mengiste et al. 2003; Yang et al. 2012; Zhang et al. 2012; Zhu et al. 2015). In rice, 233 MYB genes have been identified (Smita et al. 2015). Nevertheless, only MYB30, MYB55, and MYB110 have been validated to positively regulate rice bacterial blight resistance by activating the hydroxycinnamic acids synthesis pathway (Kishi-Kaboshi et al. 2018). Our findings in the present study enrich our knowledge about the functions of MYB genes in disease resistance. Additionally, OsMYB21 has been shown down-regulated over ustilaginoidea virens, which causes rice false smut (Wei et al. 2020). In Arabidopsis, glutathione could activate the heat shock proteins through the transcription factor MYB21 (Kumar and Chattopadhyay 2018). In Pyrus betulaefolia, MYB21 plays a positive role in drought tolerance (Li et al. 2017). Therefore, we speculate that OsMYB21 may have 
important roles in pathways for other biotic and abiotic stresses than just being a negative regulator to bacterial blight in rice.

\section{The Novel QTLs Provides a New Source for Molecular Rice Breeding and Cloning of Genes Associated with BB Resistance in Rice}

Among the 17 QTLs for BB resistance identified in this study, 4 QTLs (qBBR10-2, qBBR11-4, qBBR11-5 and $q B B R 11-6)$ were co-localized with the previously identified $R$ genes or QTLs for BB resistance and the other 13 QTLs were newly identified in the present study (Table 1 ), indicating the reliability of our GWAS analysis and the diversity of rice accessions used in this study. We have listed the predicted genes of the putative intervals of the 13 QTLs and their potential candidate genes (Table S3). We discovered that the lead SNPs of two QTLs ( $q B B R 4-1$ and $q B B R 7-1$ ) were located in the protein coding regions of genes encoding YT521-B-like protein family protein and AP2/EREBP transcription factor BABY BOOM, respectively (Table S3). AP2/EREBPs belong to a superfamily of plant-specific transcription factors that containing an AP2 domain (Li et al. 2016). According to the previous reports, many members of AP2/EREBP family have been validated to positively modulate plant disease resistance by regulating the transcription of defense-related genes (Park et al. 2001; Guo et al. 2004; Li et al. 2011; Lu et al. 2013; Giri et al. 2014). For instance, overexpression of OPBP1, an AP2/EREBPlike transcription factor of tobacco, enhances disease resistance in both tobacco and rice plants (Guo et al. 2004; Chen and Guo 2008). Thus, the BABY BOOM gene might also play a role in mediating rice against $X o o$ infection. Expect for the BABY BOOM, we also find three wall-associated protein kinases (WAK1, WAK2 and WAK29) among the candidate genes underlying $q B B R 1$ and $q B B R 4-1$ (Table S3). Generally, WAK, which has the ability to link plasma membrane to cell wall matrix, is one of the most likely target genes functioning in plant defense response by directly signaling cellular events through their cytoplasmic kinase domain ( $\mathrm{Li}$ et al. 2009). Recently, a new BB resistance gene, Xa40, was identified by using graphical mapping, and examination of the candidate genes showed that only WAK3 transcription levels displayed significant differences (Kim et al. 2015). Also, WAK25, WAK14, WAK91 and WAK92 were reported to positively regulate rice blast or Xoo resistance, while WAK112d was shown to negatively mediate rice blast resistance (Delteil et al. 2016; Harkenrider et al. 2016). Therefore, we deduced that the three WAK genes could be the candidate genes of $q B B R 1$ and $q B B R 4-1$. Further studies are needed to confirm their functions of these candidate genes in Xoo resistance through gain or loss-of function analysis. The identification of 13 novel QTLs for BB resistance provides a new source for molecular rice breeding and cloning of genes associated with $\mathrm{BB}$ resistance in rice.

\section{Conclusion}

In the present study, large $\mathrm{BB}$ resistance variations within 313 rice accessions from South China were observed. Among the 17 QTLs identified in this study, 4 QTLs were co-localized with the previously reported QTLs or Xa genes. The qBBR11-4 on chromosome 11 explained the largest phenotypic variation and was colocalized with the previously identified QTLs for BB and bacterial leaf streak resistance against diverse strains in three studies, suggesting its broad-spectrum resistance and potential value in rice breeding. Since overexpressing OsMYB21 decreased resistance to bacterial blight, OsMYB21 functions as a negative regulator in bacterial blight resistance in rice, providing a promising target in rice improvement of $\mathrm{BB}$ resistance by means of gene editing, specifically by introducing the 2-bp difference in the promoter of OsMYB21. In addition, the 13 novel QTLs for BB resistance were detected in this study and the potential candidate genes for these novel QTLs were analyzed, providing a new source for cloning of genes associated with $\mathrm{BB}$ resistance and molecular breeding in rice.

\section{Materials and Methods}

\section{Plant Materials and Pathogen}

The 313 rice core germplasms (indica rice) composed of 255 landraces and 58 modern cultivars were used for GWAS analysis (Table S1). They were collected in South China by the Rice Research Institute, Guangdong Academy of Agricultural Sciences. The 313 rice accessions represent $90 \%$ of the diversity of original collection in term of 26 traits (unpublished data). Rice cultivar Nipponbare (ssp. japonica) was used for the transgenic analysis and Chinese Xoo race 4 (CI-4) was used for evaluation of bacterial blight resistance.

\section{Sequencing, SNP Calling and Phylogenetic Analysis}

All 313 accessions were sequenced by Illumina Hiseq2000 platform. Raw sequencing reads were mapped to rice reference genome sequence version of MSU V7.0 (Kawahara et al. 2013) by Bowtie2 (Langmead and Salzberg 2013) and SNP were called and filtered according to GATK3.8 best practices pipeline (McKenna et al. 2010). SNP were then further filtered by the criteria of having less than $15 \%$ missing data and minor allele frequency (MAF) $>0.05$ by TASSEL 5.0 (Bradbury et al. 2007). Finally 643,841 SNP were identified for further phylogenetic and GWAS analysis. Maximum-Likelihood (ML) phylogenetic tree were conducted by MEGA 7.0 (Kumar et al. 2016) using all 643,841 SNP above. The 
program operating parameters were set as follows: a Tamura-Nei model with 1000 bootstrap repetitions, accompanied by uniform rates, and partial deletion of gaps/missing data.

\section{Pathogen Inoculation and Disease Severity Evaluation} For GWAS analysis, 313 rice accessions were planted in the paddy field at the experimental base of Guangdong Academy of Agricultural Sciences in Guangdong, China, in the second cropping season in 2017. The experiments were arranged in a randomized complete block design with two replicates. The field management including irrigation, fertilization, and disease and pest control, followed the conventional practice in rice production. More than 24 leaves from 8 individual plants in the middle of each line were inoculated with CI-4 at the booting stage using the leaf-clipping method (Kauffman et al. 1973). Disease was assessed by measuring the percent lesion length (lesion length/leaf length) at 2 weeks after inoculation. Since large variations in leaf length were observed among the 313 accessions used in this study, we used the "percent lesion length" for disease evaluation of the rice accession in order to better reflect the difference in disease severity among these diverse rice accessions.

For transcription analysis and phenotypic evaluation of transgenic plants, plants were grown in soil in the greenhouse and inoculated with CI-4 at the booting stage by the leaf-clipping method. Disease severity was assessed by measuring the lesion length. RNA samples for transcription analysis were collected at $0 \mathrm{~h}, 12 \mathrm{~h}, 24 \mathrm{~h}$ and $48 \mathrm{~h}$ after pathogen inoculation. The experiments were repeated twice.

\section{GWAS Analysis, QTL Delimitation and Identification of Candidate Gene}

GWAS analysis, QTL delimitation and identification of candidate gene were performed using the same method as described in our previous study (Zhao et al. 2018). Briefly, all 643,841 SNPs and GAPIT version 2 were used for GWAS analysis (Tang et al. 2016). GWAS was conducted using the mix liner model with kinship matrix, and the principle component (PC) was set to 2 in GAPIT. Manhattan and QQ plots were produced using R package qqman (Turner 2014). A QTL was declared if a region has two or more than two significant SNPs within a $200 \mathrm{~kb}$ interval. The candidate genes were searched from $200 \mathrm{~kb}$ upstream and downstream of the most significant SNP in each QTL.

\section{Real-Time PCR Analysis}

Real-time PCR was conducted using the same method as described by Liu et al. (Liu et al. 2016) with minor modifications. Total RNA was extracted from rice leaf tissues with Eastep ${ }^{\circ}$ Super Total RNA Extraction Kit (Promega Biotech Co., Ltd., USA). The PCR analysis was performed using the BioRad CFX 96 system. All experiments were repeated thrice and the gene-specific primers used in this study were listed in Table S5.

\section{Vector Construction and Rice Transformation}

The coding sequences of OsMYB21 were amplified from rice varieties $\mathrm{P} 91$ and Nipponbare, respectively, using OsMYB21OE-F/R primers (Table S5), and were then sub-cloned into the pOx overexpressing vector under control of the ubiquitin promoter. The constructed plasmids were re-checked by sequencing and transferred into Nipponbare via Agrobacterium tumefaciens EHA105 by an Agrobacterium-mediated genetic transformation approach.

\section{Abbreviations}

BB: Bacterial blight; GWAS: Genome-wide association study; BLS: Bacterial leaf streak; Xoo: Xanthomonas oryzae pv. oryzae; QTL: Quantitative trait loci;

PR: Pathogenesis-related; SNP: Single-nucleotide polymorphism; MAF: Minor allele frequency

\section{Supplementary Information}

The online version contains supplementary material available at https://doi. org/10.1186/s12284-021-00501-z.

Additional file 1: Table S1. Information on the 313 diverse genotypes used in this study.

Additional file 2: Table S2. 716 SNPs were significantly associated with bacterial blight resistance in the 313 rice accessions.

Additional file 3: Table S3. Locus overlapping or flanking the SNP identified by GWAS.

Additional file 4: Table S4. Expression detection of 11 potential genes before and after bacterial inoculation.

Additional file 5: Table S5. Primers used for quantitative RT-PCR and vector construction.

Additional file 6: Figure S1. The expression levels of five candidate genes in different rice accessions before $(0 \mathrm{~h})$ and after $(6 \mathrm{~h}, 12 \mathrm{~h}$ and 24 h) Xoo inoculation.

Additional file 7: Figure S2. Sequence variations in the promoter region of OsMYB21 between Xoo-resistant and Xoo-susceptible accessions.

Additional file 8: Figure S3. Alignment of protein sequences between Nipponbare, Xoo-resistance and Xoo-susceptible accessions.

\section{Acknowledgments}

We thank Professor Chen Li and Mr. Yu Chen from the Rice Genetic and Resource Lab, Rice Research Institute of Guangdong Academy of Agricultural Sciences for providing the core rice panel used in this study.

\section{Authors' Contributions}

$W Y, B L$, and $J L Z$ conceived and designed the experiment. W Y, Q L, SH Z conducted the experiments, performed data analysis and wrote the manuscript. SH Z, L C, TF Y, JF D, H F, YM M, L Z, J W and W L participated in material development, sample preparation and data analysis. $B L$ and $W Y$ drafted proposals and corrected the manuscript. All authors read and approved the final manuscript.

Funding

This work was supported by grants from the National Key Research and Development Project (2018YFD0200302), the Innovation Team Project of Guangdong Modern Agricultural Industrial System (2019KJ106, 2020KJ106), 
Key Areas Research Projects of Guangdong Province (2018B020202004), Special fund for scientific innovation strategy-construction of high level Academy of Agriculture Science (R2018QD-010, R2019-JX001, R2020PYJX001), Natural Science Foundation of Guangdong Province, China (2017A030313183)

\section{Availability of Data and Materials}

The datasets supporting the conclusions of this article are provided within the article and its additional files.

\section{Declarations}

\section{Ethics Approval and Consent to Participate}

No applicable.

\section{Consent for Publication}

No applicable.

\section{Competing Interests}

The authors declare that they have no competing interests.

\section{Author details}

${ }^{1}$ Rice Research Institute, Guangdong Academy of Agricultural Sciences, Guangzhou 510640, China. ${ }^{2}$ Guangdong Key Laboratory of New Technology in Rice Breeding, Guangzhou 510640, China.

Received: 27 December 2020 Accepted: 8 June 2021

Published online: 29 June 2021

\section{References}

Bossa-Castro AM, Tekete C, Raghavan C, Delorean EE, Dereeper A, Dagno K, Koita O, Mosquera $G$, Leung $H$, Verdier V, Leach JE (2018) Allelic variation for broad-spectrum resistance and susceptibility to bacterial pathogens identified in a rice MAGIC population. Plant Biotechnol J 16(9):1559-1568. https://doi.org/10.1111/pbi.12895

Bradbury PJ, Zhang ZW, Kroon DE, Casstevens TM, Ramdoss Y, Buckler ES (2007) TASSEL: software for association mapping of complex traits in diverse samples. Bioinformatics 23(19):2633-2635. https://doi.org/10.1093/bioinforma tics/btm308

Cao YL, Duan L, Li HJ, Sun XL, Zhao Y, Xu CG, Li XH, Wang SP (2007) Functional analysis of $\mathrm{Xa3} / \mathrm{Xa} 26$ family members in rice resistance to Xanthomonas oryzae pv. Oryzae. Theor Appl Genet 115(7):887-895. https://doi.org/10.1007/ s00122-007-0615-0

Chen XJ, Guo ZJ (2008) Tobacco OPBP1 enhances salt tolerance and disease resistance of transgenic rice. Int J Mol Sci 9(12):2601-2613. https://doi.org/1 0.3390/ijms9122601

Delteil A, Gobbato E, Cayrol B, Estevan J, Michel-Romiti C, Dievart A, Kroj T, Morel JB (2016) Several wall-associated kinases participate positively and negatively in basal defense againstrice blast fungus. BMC Plant Biol 16(1):17. https://doi. org/10.1186/s12870-016-0711-X

Deng HQ, Liu HB, Li XH, Xiao JH, Wang SP (2012) A CCCH-type zinc finger nucleic acid-binding protein quantitatively confers resistance against rice bacterial blight disease. Plant Physiol 158(2):876-889. https://doi.org/10.1104/ pp.111.191379

Dilla-Ermita CJ, Tandayu E, Juanillas VM, Detras J, Lozada DN, Dwiyanti MS, Cruz CV, Mbanjo EGN, Ardales E, Diaz MG, Mendioro M, Thomson MJ, Kretzschmar T (2017) Genome-wide association analysis tracks bacterial leaf blight resistance loci in rice diverse germplasm. Rice 10(1):8. https://doi.org/10.11 86/s12284-017-0147-4

Djedatin G, Ndjiondjop MN, Sanni A, Lorieux M, Verdier V, Ghesquiere A (2016) Identification of novel major and minor QTLs associated with Xanthomonas oryzae pv. oryzae (African strains) resistance in rice (Oryza sativa L.). Rice 9:18

Germain H, Lachance D, Pelletier G, Fossdal CG, Solheim H, Séguin A (2012) The expression pattern of the Picea glauca Defensin 1 promoter is maintained in Arabidopsis thaliana, indicating the conservation of signalling pathways between angiosperms and gymnosperms. J Exp Bot 63(2):785-795. https:// doi.org/10.1093/jxb/err303

Giri MK, Swain S, Gautam JK, Singh S, Singh N, Bhattacharjee L, Nandi AK (2014) The Arabidopsis thaliana At4g13040 gene, a unique member of the AP2/ EREBP family, is a positive regulator for salicylic acid accumulation and basal defense against bacterial pathogens. J Plant Physiol 171(10):860-867. https:// doi.org/10.1016/j.jplph.2013.12.015

Grau J, Wolf A, Reschke M, Bonas U, Posch S, Boch J (2013) Computational predictions provide insights into the biology of Tal effector target sites. PLoS Comput Biol 9(3):e1002962. https://doi.org/10.1371/journal.pcbi.1002962

Guo ZI, Chen XJ, Wu XL, Ling JQ, Xu P (2004) Overexpression of the AP2/EREBP transcription factor OPBP1 enhances disease resistance and salt tolerance in tobacco. Plant Mol Biol 55(4):607-618. https:/doi.org/10.1007/s11103-004-1521-3

Gustave D, Marie-Noelle N, Ambaliou S, Mathias L, Valérie V, Alain G (2016) Identification of novel major and minor QTLS associated with Xanthomonas oryzae pv. oryzae (African strains) resistance in rice (Oryza sativa L.). Rice 9(1): 18. https://doi.org/10.1186/s12284-016-0090-9

Han B, Huang XH (2013) Sequencing-based genome-wide association study in rice. Curr Opin Plant Biol 16(2):133-138. https://doi.org/10.1016/j.pbi.2013.03.006

Han XY, Yang Y, Wang XM, Zhou J, Zhang WH, Yu CL, Cheng C, Cheng Y, Yan CQ, Chen JP (2014) Quantitative trait loci mapping for bacterial blight resistance in rice using bulked segregant analysis. Int J Mol Sci 15(7):1184711861. https://doi.org/10.3390/ijms150711847

Harkenrider M, Sharma R, Vleesschauwer DD, Tsao L, Zhang XT, Chern M, Canlas P, Zuo SM, Ronald PC (2016) Overexpression of rice wall-associated kinase 25 (OsWAK25) alters resistance to bacterial and fungal pathogens. PLoS One 11(1):e0147310. https://doi.org/10.1371/journal.pone.0147310

Hu KM, Cao JB, Zhang J, Xia F, Ke YG, Zhang HT, Xie WY, Liu HB, Cui Y, Cao YL, Sun XL, Xiao JH, Li XH, Zhang QL, Wang SP (2017) Improvement of multiple agronomic traits by a disease resistance gene via cell wall reinforcement. Nat Plants 3(3):17009. https://doi.org/10.1038/nplants.2017.9

Huang N, Angeles ER, Domingo J, Magpantay G, Singh S, Zhang G, Kumaravadivel N, Bennett J, Khush GS (1997) Pyramiding of bacterial blight resistance genes in rice: marker-assisted selection using RFLP and PCR. Theor Appl Genet 95(3):313-320. https://doi.org/10.1007/s001220050565

Hutin M, Sabot F, Ghesquiere A, Koebnik R, Szurek B (2015) A knowledge-based molecular screen uncovers a broad-spectrum OsSWEET14 resistance allele to bacterial blight from wild rice. Plant J 84(4):694-703. https://doi.org/10.1111/tpj.13042

Ji ZY, Wang CL, Zhao KJ (2018) Rice routes of countering Xanthomonas oryzae. Int J Mol Sci 19(10):3008. https://doi.org/10.3390/ijms19103008

Jiang N, Yan J, Liang Y, Shi YL, He ZZ, Wu YT, Zeng Q, Liu XL, Peng JH (2020) Resistance genes and their interactions with bacterial blight/leaf streak pathogens (Xanthomonas oryzae) in rice (Oryza sativa L.)- an updated review. Rice 13:3

Kauffman HE, Reddy APK, Hsieh SPY, Merca SD (1973) An improved technique for evaluation of resistance of rice varieties to Xanthomonas oryzea. Plant Dis Rep 57:537-541

Kawahara Y, Bastide MDL, Hamilton JP, Kanamori H, McCombie WR, Ouyang S, Schwartz DC, Tanaka T, Wu JZ, Zhou SG, Childs KL, Davidson RM, Lin HN, Quesada-Ocampo L, Vaillancourt B, Sakai H, Lee SS, Kim J, Numa H, Itoh T, Buell CR, Matsumoto T (2013) Improvement of the Oryza sativa Nipponbare reference genome using next generation sequence and optical map data. Rice 6(1):4. https://doi.org/10.1186/1939-8433-6-4

Kim SM (2018) Identifcation of novel recessive gene $x a 44(t)$ conferring resistance to bacterial blight races in rice by QTL linkage analysis using an SNP chip. Theor Appl Genet 131(12):2733-2743. https://doi.org/10.1007/s00122-018-3187-2

Kim SM, Reinke RF (2019) A novel resistance gene for bacterial blight in rice, Xa43(t) identified by GWAS, confirmed by QTL mapping using a bi-parental population. PLoS One 14(2):e0211775. https://doi.org/10.1371/journal.pone.0211775

Kim SM, Suh JP, Qin Y, Noh TH, Reinke RF, Jena KK (2015) Identification and finemapping of a new resistance gene, $\mathrm{X} a 40$, conferring resistance to bacterial blight races in rice (Oryza sativa L.). Theor Appl Genet 128(10):1933-1943. https://doi.org/10.1007/s00122-015-2557-2

Kishi-Kaboshi M, Seo S, Takahashi A, Hirochika H (2018) The MAMP-responsive MYB transcription factors MYB30, MYB55 and MYB110 activate the HCAA synthesis pathway and enhance immunity in rice. Plant Cell Physiol 59(5): 903-915. https://doi.org/10.1093/pcp/pcy062

Kumar D, Chattopadhyay S (2018) Glutathione modulates the expression of heat shock proteins via the transcription factors BZIP10 and MYB21 in Arabidopsis. J Exp Bot 69(15):3729-3743. https://doi.org/10.1093/jxb/ery166

Kumar S, Stecher G, Tamura K (2016) MEGA7: molecular evolutionary genetics analysis version 7.0 for bigger datasets. Mol Boil Evol 33(7):1870-1874. https://doi.org/10.1093/molbev/msw054

Langmead B, Salzberg SL (2013) Fast gapped-read alignment with bowtie 2. Nat Methods 9:357-359

Li B, Li QR, Mao XG, Li A, Wang JY, Chang XP, Hao CY, Zhang XY, Jing RL (2016) Two novel AP2/EREBP transcription factor genes TaPARG have pleiotropic 
functions on plant architecture and yield-related traits in common wheat. Front Plant Sci 7:1191

Li CW, Su RC, Cheng CP, Sanjaya YSJ, Hsieh TH, Chao TC, Chan MT (2011) Tomato RAV transcription factor is a pivotal modulator involved in the AP2/ EREBPmediated defense pathway. Plant Physiol 156(1):213-227. https://doi.org/1 $0.1104 / p p .111 .174268$

Li H, Zhou SY, Zhao WS, Su SC, Peng YL (2009) A novel wall-associated receptorlike protein kinase gene, OsWAK1, plays important roles in rice blast disease resistance. Plant Mol Biol 69(3):337-346. https://doi.org/10.1007/s11103-0089430-5

Li KQ, Xing CH, Yao ZH, Huang XS (2017) PbrMYB21, a novel MYB protein of Pyrus betulaefolia, functions in drought tolerance and modulates polyamine levels by regulating arginine decarboxylase gene. Plant Biotechnol J 15(9): 1186-1203. https://doi.org/10.1111/pbi.12708

Li ZK, Arif M, Zhong DB, Fu BY, Xu JL, Domingo-Rey J, Ali J, Vijauakumar CHM, Yu SB, Khush GS (2006) Complex genetic networks underlying the defensive system of rice (Oryza sativa L.) to Xanthomonas oryzae pv. Oryzae. Proc Natl Acad Sci 103(21):7994-7999. https://doi.org/10.1073/pnas.0507492103

Liu Q, Yang JY, Yan SJ, Zhang SH, Zhao JL, Wang WJ, Yang TF, Wang XF, Mao XX, Dong JF, Zhu XY, Liu B (2016) The germin-like protein OsGLP2-1 enhances resistance to fungal blast and bacterial blight in rice. Plant Mol Biol 92(4-5): 411-423. https://doi.org/10.1007/s11103-016-0521-4

Liu X, Yang LH, Zhou XY, Zhou MP, Lu Y, Ma LJ, Ma HX, Zhang ZY (2013) Transgenic wheat expressing Thinopyrum intermedium MYB transcription factor TiMYB2R-1 shows enhanced resistance to the take-all disease. J Exp Bot 64(8):2243-2253. https://doi.org/10.1093/jxb/ert084

Lu X, Zhang L, Zhang FY, Jiang WM, Shen Q, Zhang LD, Lv ZY, Wang GF, Tang KX (2013) AaORA, a trichome-specific AP2/ERF transcription factor of Artemisia annua, is a positive regulator in the artemisinin biosynthetic pathway and in disease resistance to Botrytis cinerea. New Phytol 198(4): 1191-1202. https://doi.org/10.1111/nph.12207

McKenna A, Hanna M, Banks E, Sivachenko A, Cibulskis K, Kernytsky A, Garimella K, Altshuler D, Gabriel S, Daly M, DePristo MA (2010) The genome analysis toolkit: a mapreduce framework for analyzing next-generation DNA sequencing data. Genome Res 20(9):1297-1303. https://doi.org/10.1101/gr.1 07524.110

Mengiste T, Chen X, Salmeron J, Dietrich R (2003) The BOTRYTIS SUSCEPTIBLE1 gene encodes an R2R3MYB transcription factor protein that is required for biotic and abiotic stress responses in Arabidopsis. Plant Cell 15(11):2551-2565. https://doi.org/10.1105/tpc.014167

Park JM, Park CJ, Lee SB, Ham BK, Shin R, Paek KH (2001) Overexpression of the tobacco TsiT gene encoding an EREBP/AP2-type transcription factor enhances resistance against pathogen attack and osmotic stress in tobacco. Plant Cell 13(5):1035-1046. https://doi.org/10.1105/tpc.13.5.1035

Ramalingam J, Cruz CMV, Kukreja K, Chittoor JM, Wu JL, Lee SW, Baraoidan M (2003) Candidate defense genes from rice, barley, and maize and their association with qualitative and quantitative resistance in rice. Mol Plant Microbe In 16(1):14-24. https://doi.org/10.1094/MPMI.2003.16.1.14

Savary S, Willocquet L, Pethybridge SJ, Esker P, McRoberts N, Nelson A (2019) The global burden of pathogens and pests on major food crops. Nat Ecol Evol 3(3):430-439. https://doi.org/10.1038/s41559-018-0793-y

Shan TL, Rong W, Xu HJ, Du LP, Liu X, Zhang ZY (2016) The wheat R2R3-MYB transcription factor TaRIM1 participates in resistance response against the pathogen Rhizoctonia cerealis infection through regulating defense genes. Sci Rep 6(1):28777. https://doi.org/10.1038/srep28777

Smita S, Katiyar A, Chinnusamy V, Pandey DM, Bansal KC (2015) Transcriptional regulatory network analysis of MYB transcription factor family genes in rice. Front Plant Sci 6:1157

Sun X, Yang Z, Wang S, Zhang Q (2003) Identification of a 47-kb DNA fragment containing Xa4, a locus for bacterial blight resistance in rice. Theor Appl Genet 106(4):683-687. https://doi.org/10.1007/s00122-002-1117-8

Takeda S, Matsuoka M (2008) Genetic approaches to crop improvement: responding to environmental and population changes. Nat Rev Genet 9(6): 444-457. https://doi.org/10.1038/nrg2342

Tang Y, Liu XL, Wang JB, Li M, Wang QS, Tian F, Su ZB, Pan YC, Liu D, Lipkai A, Buckler E, Zhang ZW (2016) GAPIT version 2: an enhanced integrated tool for genomic association and prediction. The Plant Genome 9:2

Turner SD (2014) Qqman: an R package for visualizing GWAS results using Q-Q and Manhattan plots. BioRxiv. https://doi.org/10.1101/005165

Wang CL, Zhang XP, Fan YL, Gao Y, Zhu QL, Zheng CK, Qin TF, Li YQ, Che JY, Zhang MW, Yang B, Liu YG, Zhao KJ (2015) XA23 is an executor R protein and confers broad-spectrum disease resistance in rice. Mol Plant 8(2):290302. https://doi.org/10.1016/..molp.2014.10.010

Wang Q, Tang JL, Han B, Huang XH (2020) Advances in genome-wide association studies of complex traits in rice. Theor Appl Genet 133(5):1415-1425. https:// doi.org/10.1007/s00122-019-03473-3

Wei SH, Wang YL, Zhou JM, Xiang SB, Sun WX, Peng XW, Li J, Hai YF, Wang Y, Li $S$ (2020) The conserved effector UvHrip1 interacts with OsHGW, and infection of ustilaginoidea virens regulates defense- and heading date-related signaling pathway. Int J Mol Sci 21(9):3376. https://doi.org/10.3390/ijms21 093376

Yang A, Dai X, Zhang WH (2012) A R2R3-type MYB gene, OsMYB2, is involved in salt, cold, and dehydration tolerance in rice. J Exp Bot 63(7):2541-2556. https://doi.org/10.1093/jxb/err431

Yoshimura S, Yamanouchi U, Katayose Y, Toki S, Wang ZX, Kono I, Kurata N, Yano M, Iwata N, Sasaki T (1998) Expression of Xa1, a bacterial blight-resistance gene in rice, is induced by bacterial inoculation. Proc Natl Acad Sci 95(4): 1663-1668. https://doi.org/10.1073/pnas.95.4.1663

Zhai LY, Zheng TQ, WangXY WY, Chen K, Wang S, Wang Y, Xu JL, Li ZK (2018) QTL mapping and candidate gene analysis of peduncle vascular bundle related traits in rice by genome-wide association study. Rice 11(1):13. https:// doi.org/10.1186/s12284-018-0204-7

Zhang F, Wu ZC, Wang MM, Zhang FF, Dingkuhn M, Xu JL, Zhou YL, Li ZK (2017) Genome-wide association analysis identifies resistance loci for bacterial blight in a diverse collection of indica rice germplasm. PLoS One 12(3):e0174598. https://doi.org/10.1371/journal.pone.0174598

Zhang F, Xie XW, Xu MR, Wang WS, Xu JL, Zhou YL, Li ZK, Ahn SN (2015) Detecting major QTL associated with resistance to bacterial blight using a set of rice reciprocal introgression lines with high density SNP markers. Plant Breed 134(3):286-292. https://doi.org/10.1111/pbr.12256

Zhang ZY, Liu X, Wang XD, Zhou MP, Zhou XY, Ye XG, Wei XN (2012) An R2R3 MYB transcription factor in wheat, TaPIMP1, mediates host resistance to Bipolaris Sorokiniana and drought stresses through regulation of defense-and stress-related genes. New Phytol 196(4):1155-1170. https://doi.org/10.1111/ j.1469-8137.2012.04353.x

Zhao JL, Yang W, Zhang SH, Yang TF, Liu Q, Dong JF, Fu H, Mao XX, Liu B (2018) Genome-wide association study and candidate gene analysis of rice cadmium accumulation in grain in a diverse rice collection. Rice 11(1):61. https://doi.org/10.1186/s12284-018-0254-x

Zhao K, Tung CW, Eizenga GC, Wright MH, Ali ML, Price AH, Norton GJ, Islam MR, Reynolds A, Mezey J, McClung AM, Bustamante CD, McCouch SR (2011) Genome-wide association mapping reveals a rich genetic architecture of complex traits in Oryza sativa. Nat Commun 2(1):467. https://doi.org/10.1038/ ncomms 1467

Zhu N, Cheng S, Liu X, Du H, Dai M, Zhou DX, Yang W, Zhao Y (2015) The R2R3type MYB gene OSMYB91 has a function in coordinating plant growth and salt stress tolerance in rice. Plant Sci 236:146-156. https://doi.org/10.1016/j. plantsci.2015.03.023

\section{Publisher's Note}

Springer Nature remains neutral with regard to jurisdictional claims in published maps and institutional affiliations.

\section{Submit your manuscript to a SpringerOpen ${ }^{\circ}$ journal and benefit from:}

- Convenient online submission

- Rigorous peer review

- Open access: articles freely available online

- High visibility within the field

- Retaining the copyright to your article

Submit your next manuscript at $\boldsymbol{\nabla}$ springeropen.com 